\title{
Sufficient oxygen redox activation against voltage decay in Li-rich layered oxide cathode materials
}

\author{
Yuhuan Zhou ${ }^{1,2,}$, Hongfu Cui ${ }^{1}$,, Bao Qiu ${ }^{1,2, *}$, Yuanhua Xia ${ }^{3}$, Chong Yin ${ }^{1,2}$, Liyang \\ $\mathrm{Wan}^{1}{ }^{\text {, Zhepu Shi }}{ }^{1,4}$ and Zhaoping Liu ${ }^{1,2, *}$ \\ ${ }^{1}$ Ningbo Institute of Materials Technology and Engineering (NIMTE), Chinese Academy of \\ Sciences, Ningbo 315201, PR China \\ ${ }^{2}$ University of Chinese Academy of Sciences, Beijing 100049, PR China \\ ${ }^{3}$ Institute of Nuclear Physics and Chemistry, China Academy of Engineering Physics, Mianyang \\ 621999, PR China \\ ${ }^{4}$ Department of Chemical and Environmental Engineering, Faculty of Science and Engineering, \\ University of Nottingham Ningbo China, Taikang East Road 199, Ningbo 315100, PR China
}

\section{Support information}

\section{Methods}

\section{Synthesis of Li-rich cathode material}

Conventional co-precipitation method was taken to prepare precursors of $\mathrm{Mn}$ rich layered cathode materials. The detailed procedure was described in our previous report. Stoichiometric $\mathrm{Ni}, \mathrm{Co}$ and $\mathrm{Mn}$ sulfate solutions ( $\mathrm{Ni}: \mathrm{Co}: \mathrm{Mn}=1: 1: 8$ ) were pumped into a continuous stirred tank reactor (CSTR). $\mathrm{Na}_{2} \mathrm{CO}_{3}$ and ammonia mixed aqueous solution were used as precipitant and complexant. The $\mathrm{pH}$ value was controlled at $7.0 \sim 8.0$. The reaction temperature was set at $60{ }^{\circ} \mathrm{C}$. The stirring speed was set at $250 \mathrm{r} / \mathrm{min}$. when the reaction finished, the formed suspension was aged for $24 \mathrm{~h}$. Then through washing and dry, the final precursor powder was collected. Lithiation of the carbonate precursor uses solid-state method. The lithium source LiOH were added to precursor with a molar ratio of 1.6: 1 . They were mixed by planetary ball milling with alcohol as a dispersant. After 4 hours of ball milling with stirring speed of $200 \mathrm{r} / \mathrm{min}$, LiOH had thoroughly mixed with precursor. The obtained slurry was then dried in vacuum for $4 \mathrm{~h}$ to obtained mixed powder. The powder was first heated in $400{ }^{\circ} \mathrm{C}$ for $5 \mathrm{~h}$, followed by a $800{ }^{\circ} \mathrm{C} 12 \mathrm{~h}$ calcining process in the air.

\section{Electrochemical measurements}

The cathode powder, acetylene black and polyvinylidene fluoride (PVDF) binder were dispersed in n-methyl-2-pyrrolidone (NMP) with a mass ratio of 8:1:1. After stirring for $12 \mathrm{~h}$, the slurry was casted on the collector aluminum foil and dried at $80^{\circ} \mathrm{C}$ for $12 \mathrm{~h}$ to remove the NMP solvent and traces water. The cathode electrode was processed into discs of $13-\mathrm{mm}$ diameter using sheet-punching machine. Finally, CR2032 coin cells were assembled in glove box full of argon with Li mental as the counter electrode and Celgard 2502 as the separator. The electrolyte was $1 \mathrm{M} \mathrm{LiPF}_{6}$ 
dissolved in ethylene carbonate (EC), dimethyl carbonate (DMC), and the volume ratio of ethylene carbonate to diethyl carbonate is 3:7. The cells were cycled galvanostatically on a LAND-CT2001A battery system. The voltage range was $2.0-4.8$ vs. $\mathrm{Li}^{+} / \mathrm{Li}^{0} \mathrm{~V}$, and the current density was $200 \mathrm{~mA} \mathrm{~g}^{-1}$ for $1.0 \mathrm{C}$. The initial activation was carried out at $10 \mathrm{~mA} \mathrm{~g}^{-1}$ before subsequent electrochemical tests for all cells at room temperature.

\section{Material characterizations}

The morphology of the as-prepared cathode materials was observed by Field emission scanning electron microscope (FESEM, Hitachi S-4800). High resolution transmission electron microscope images (HRTEM) and selected area electron diffraction (SAED) were characterized by transmission electron microscope (TEM, Talos F200x). The TEM specimen were prepared by dispersing the sample powder in alcohol and loaded on a holey copper grid. All images were shown in Figure S1.

Chemical valence changes of lattice oxygen during the first cycle were investigated by X-ray photoelectron spectroscopy measurements (XPS, Kratos AXIS Ultra DLD). Sample powders with different state of charge (SOC) were collected. To ensure enough detection depth, gallium ion beam was used to bombard the samples for $1 \mathrm{~min}$. The surface of each sample was etched for about $20 \mathrm{~nm}$. The XPS data was collected through an AXIS Ultra DLD spectrometer with AI Ka (1486.6 eV) radiation. The fitting of specific peaks refers to the previous research. The $\mathrm{O}^{2-}$ was fixed at 529.5 $\mathrm{eV}$ assuming its position does not change with state of charges to calibrate the binding energy scale ${ }^{1}$.

Synchrotron X-ray diffraction (SXRD) data was obtained at the beamline BL14B1 of the Shanghai Synchrotron Radiation Facility (SSRF). MarCCD 225 area detector was used to collect original powder polycrystalline diffraction rings of samples. The exposure time was set at $30 \mathrm{~s}$ to get sufficient clarity. All characteristic diffraction rings were guaranteed to be detected by adjusting the distance between the sample and the detector, and lanthanum hexaboride was selected to calibration the distance. The obtained data was converted from 2D to 1D using software fit2D2.

High resolution neutron diffraction (HRND) was characterized at beamline Xuanwu of 20MW China Mianyang Research Reactor. Details refers to the reference ${ }^{3}$. About $3 \mathrm{~g}$ of sample powder was used to fill a $4 \mathrm{ml}$ TiZr-alloy can, whose specification is $\phi 8 \mathrm{~mm} \times 6 \mathrm{~cm}$. Ge (511) monochromator was used to screen the neutron beam, providing a constant neutron wavelength $\lambda=1.885 \AA$. 65 identical ${ }^{3} \mathrm{He}$ filled proportional counters were utilized as detector array. Its diffraction angles can cover $10-170{ }^{\circ}$ with high angular resolution (best resolution 1.6\%o). The 1D diffraction pattern was generated through recording the neutron counts by integrating the whole vertical diffraction-neutron-signals of the Debye-Scherrer cones. The obtained data was simultaneous refinement with SXRD data using software Fullprof based on Rietveld method ${ }^{4}, 5$.

X-ray absorption spectroscopy was taken to investigate the chemical and coordination environments of transition metals for the pristine sample. $\mathrm{Ni}$, $\mathrm{Co}$ and $\mathrm{Mn}$ 
K-edges data were collected using transmission mode at the KMC-2 beamline of the synchrotron BESSY at Helmholtz-Zentrum Berlin, Germany. To calibrate zero energy $\left(E_{0}\right)$, foils of $\mathrm{Ni}, \mathrm{Co}$ and $\mathrm{Mn}$ were simultaneously measured with pristine sample. Data of X-ray absorption near-edge fine structure was extracted through the ATHENA software package by established methods.

The evolution of the global structures were characterized by laboratory in(ex) situ X-ray diffractometer (D8 Advance, Bruker AXS) using $\mathrm{Cu} K \alpha$ radiation. For the temperature-dependent in situ XRD, the sample was loaded on a disk, which was wound by heating resistance wire. The XRD patterns were collected every $20{ }^{\circ} \mathrm{C}$ from room temperature to $400{ }^{\circ} \mathrm{C}$. Each pattern was collected at the range of $10-50{ }^{\circ}(2 \theta)$ for 2 hours. The lattice parameters from the in situ XRD were calculated via the peak positions of (003) and (104) based on Bragg equation.

In situ Raman spectroscopy was carried out using Renishaw inVia Reflex Raman microscope. Sample powders pressed into sheet were fixed in the heating device with $\mathrm{N}_{2}$ as protective atmosphere. The laser with wavelength $532 \mathrm{~nm}$ was selected as the illuminant with around $1 \mu \mathrm{m}$ diameter. The power of the laser was set below $1 \mathrm{~mW} / \mu \mathrm{m}^{2}$ to avoid sample damage. The acquisition time of each Raman spectrum was $12 \mathrm{~s}$ to 5 times for every $20{ }^{\circ} \mathrm{C}$ from room temperature to $300{ }^{\circ} \mathrm{C}$. The laser spot was constantly adjusted through microscope to make the beam stay at the same place during heating. The collected Raman spectrums were fitted using Gauss and Voigt functions. 

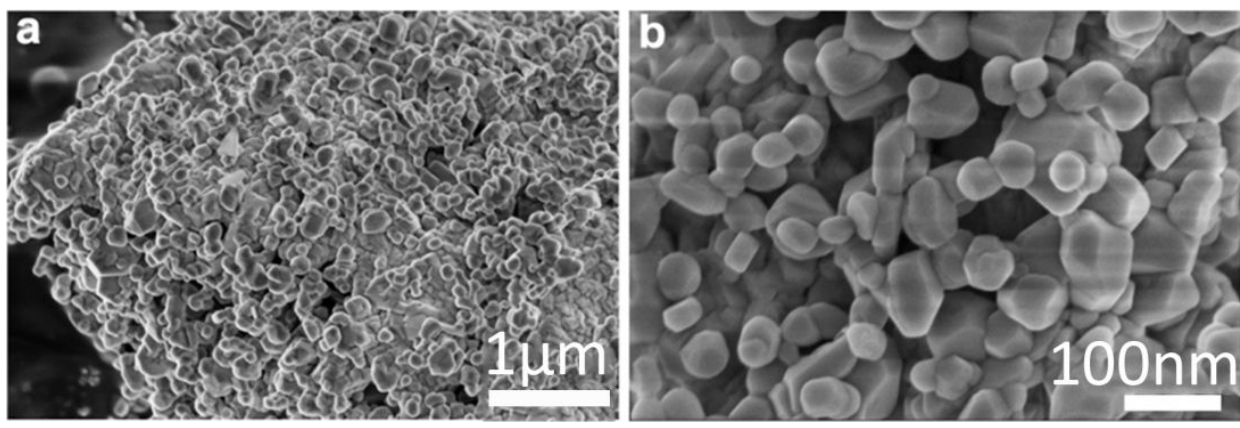

Figure S1. Low and magnified SEM images of the as-prepared $\mathrm{Li}_{1.26} \mathrm{Ni}_{0.0741} \mathrm{Co}_{0.0741} \mathrm{Mn}_{0.593} \mathrm{O}_{2}$ 
a
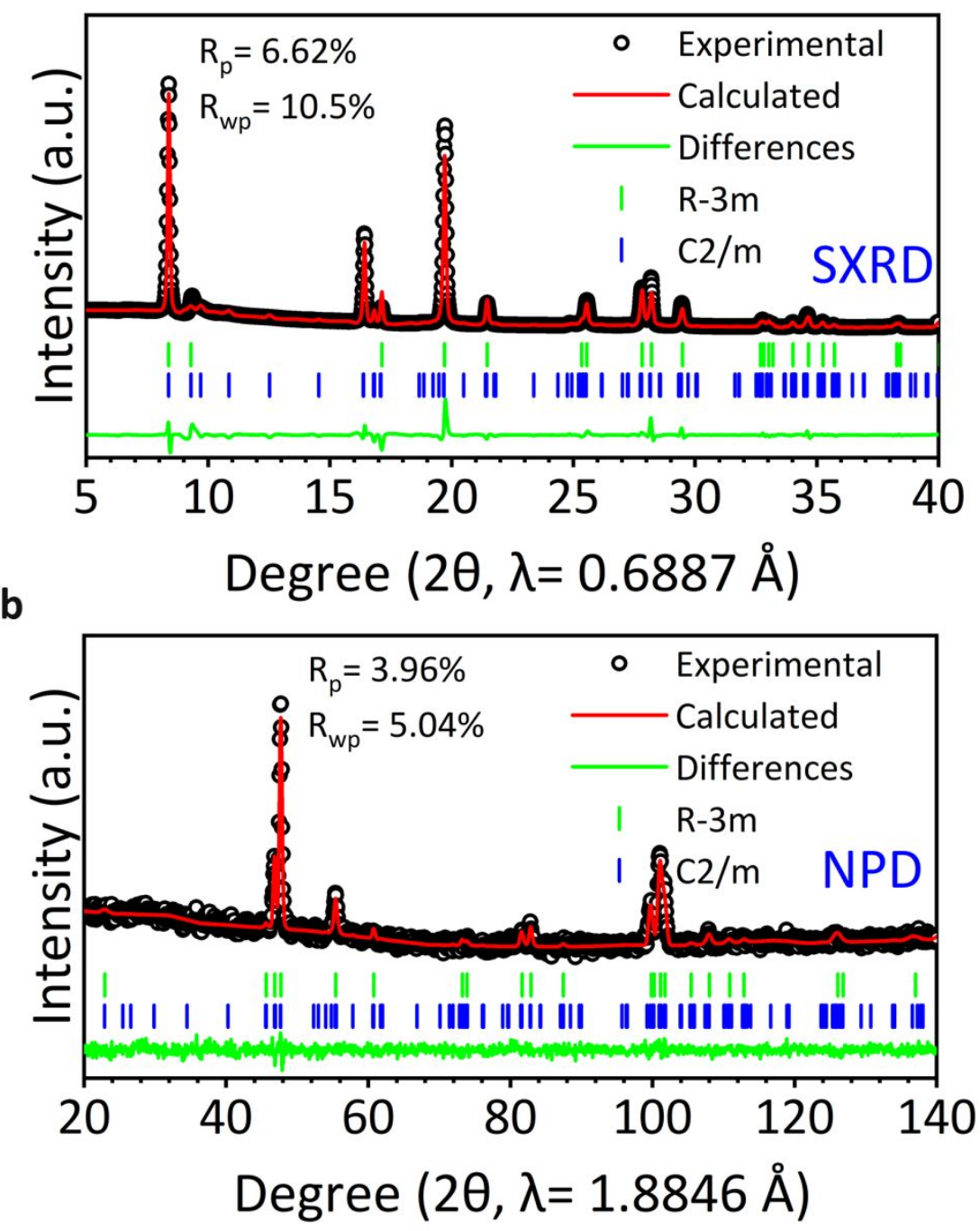

Figure S2. Joint refinement of XRD and ND patterns using the two-phase model. 
a

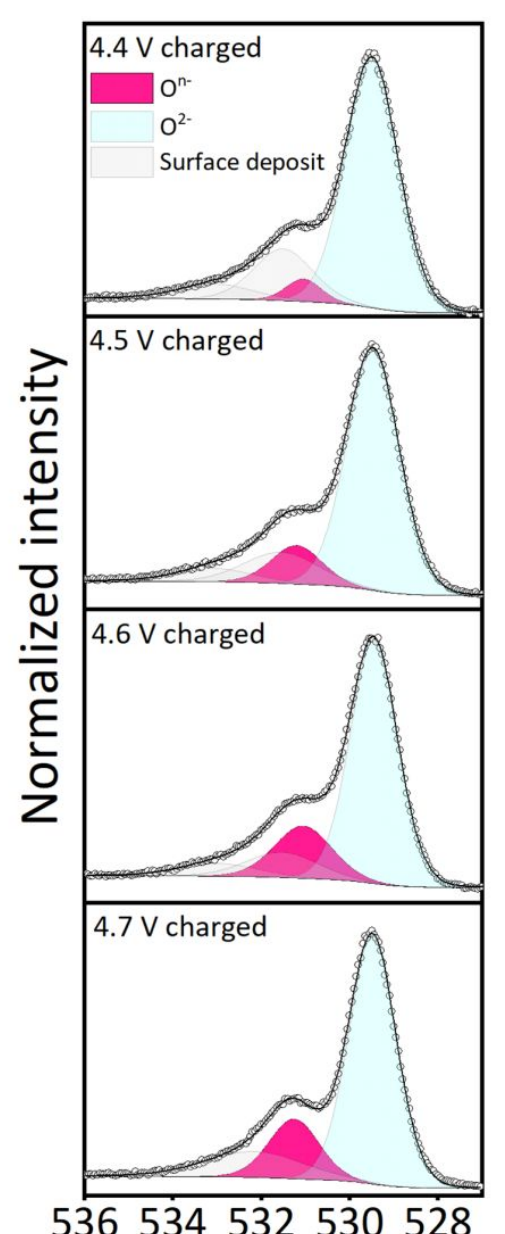

c Binding energy (eV)

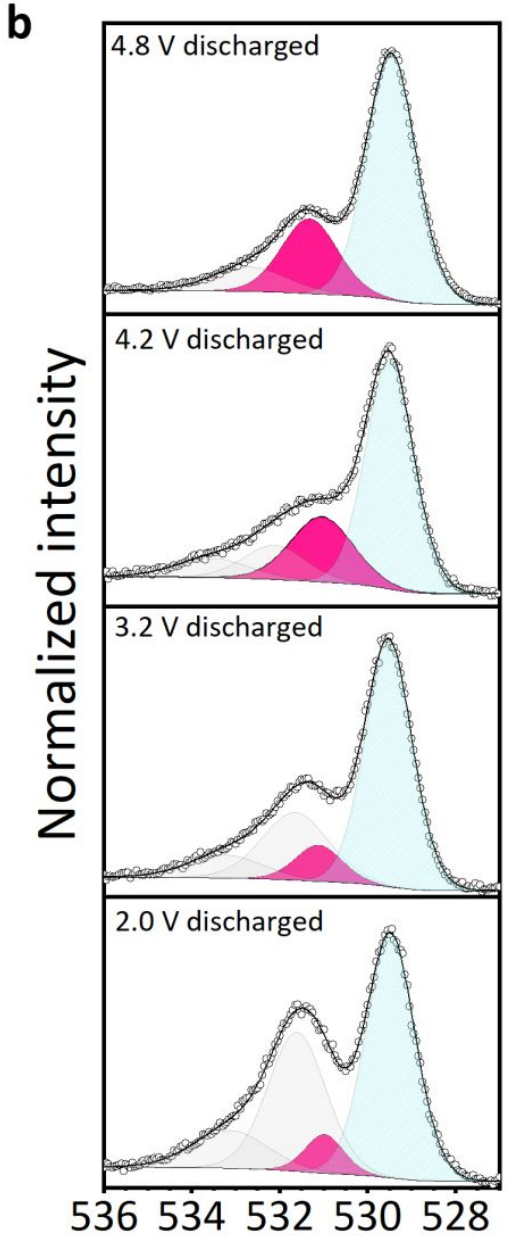

Binding energy (eV)

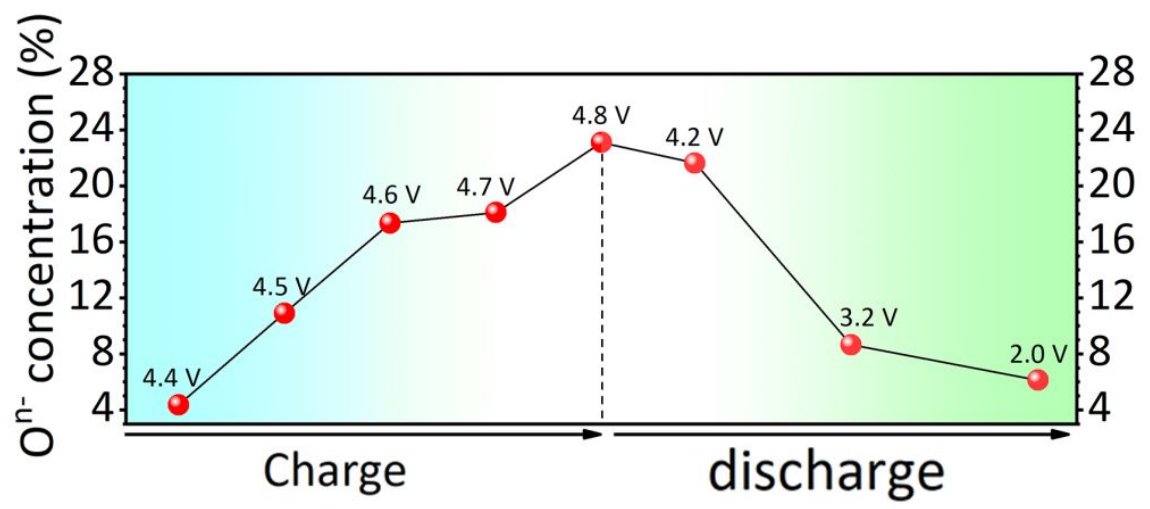

Figure S3. a, b. Evolution of the $\mathrm{O}$ 1s during the initial cycle by ex situ XPS. c. Relative concentration of $\mathrm{O}^{\text {n- }}$ representing the degree of $\mathrm{OR}$. 


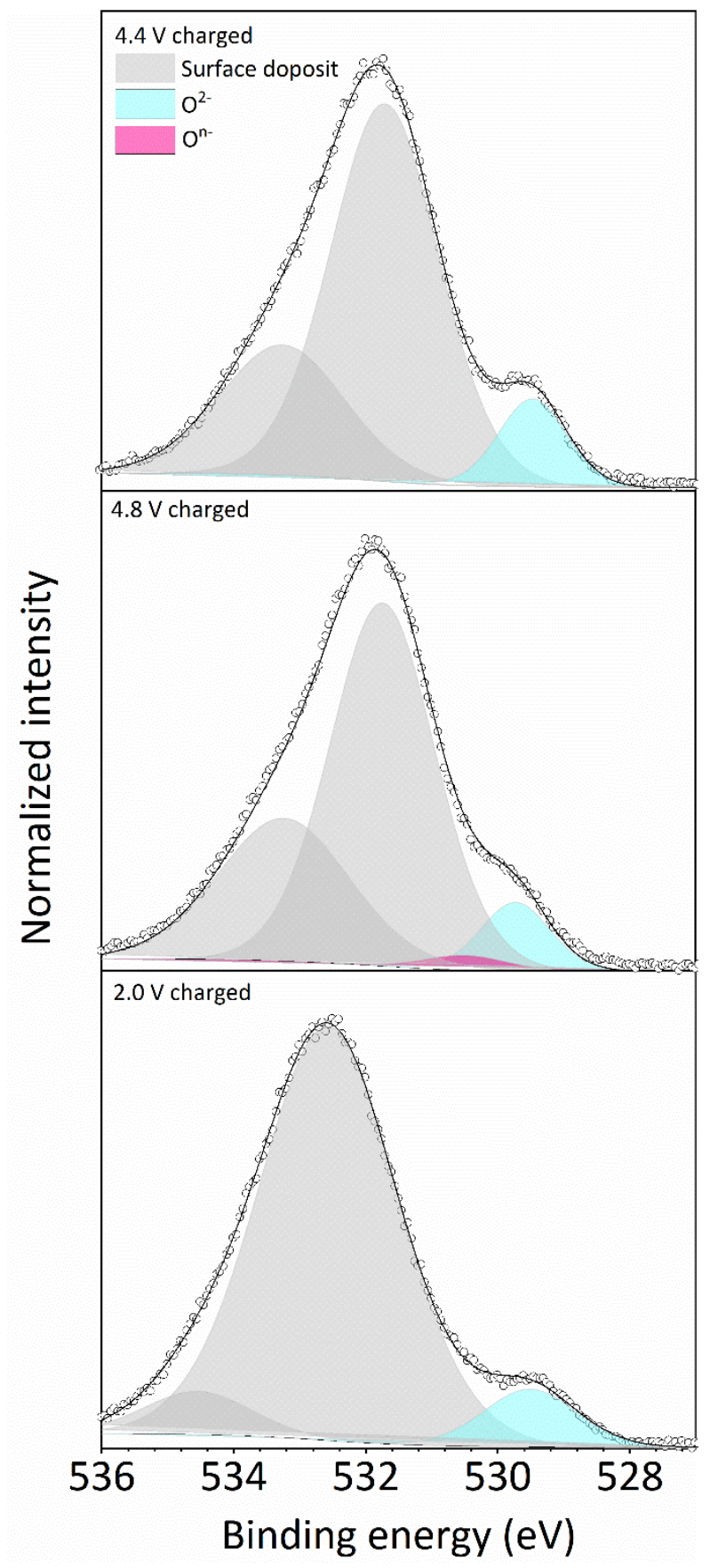

Figure S4. Evolution of the $\mathrm{O}$ 1s during the 21th cycle by ex situ XPS. 


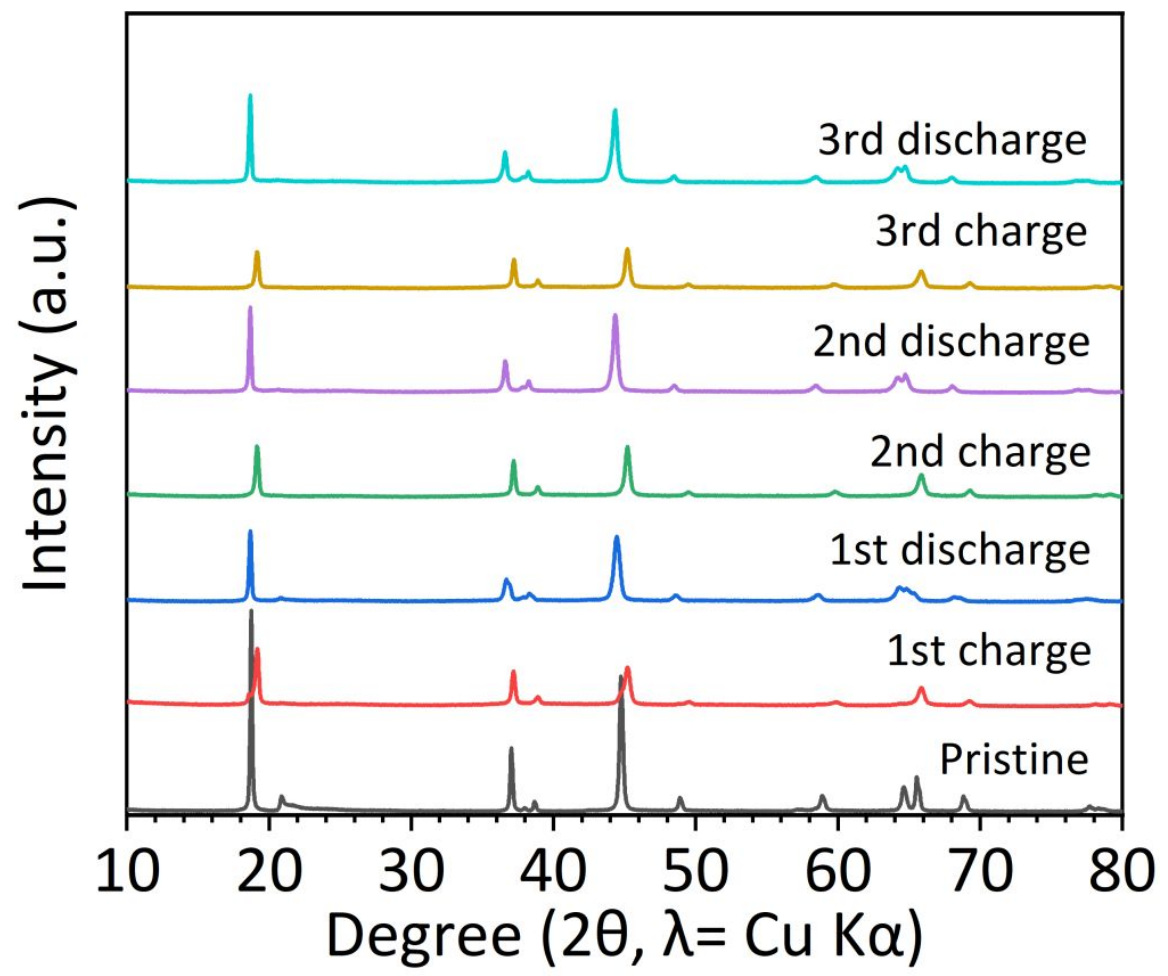

Figure S5. XRD patterns of the SOR-LLO at different state of charge during the first 3 cycles. 


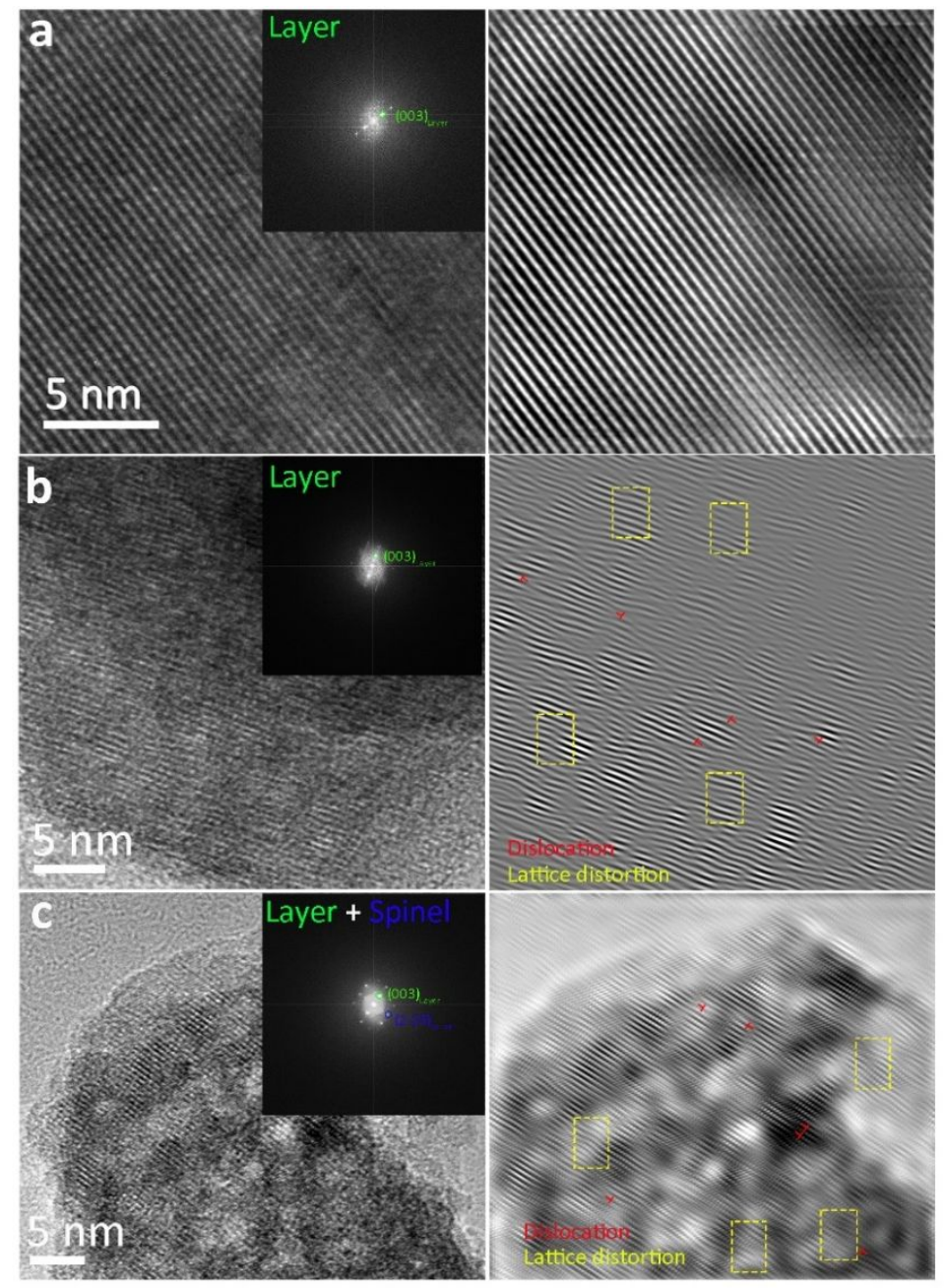

Figure S6. HRTEM, FFT and IFFT images of a. Pristine, b. initial cycled and c. 20th cycled samples. The remarked regions highlight the disordered structures including lattice distortion and dislocation in the bulk after different cycles. 
a

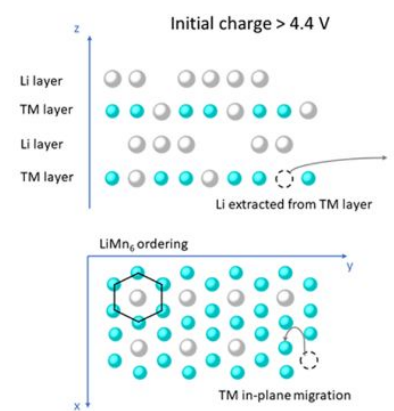

Followed discharge to $2.0 \mathrm{~V}$ Li inserted only in Li laver ००००००००० 000000000 ०००००००००

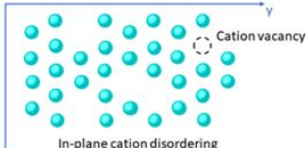

b

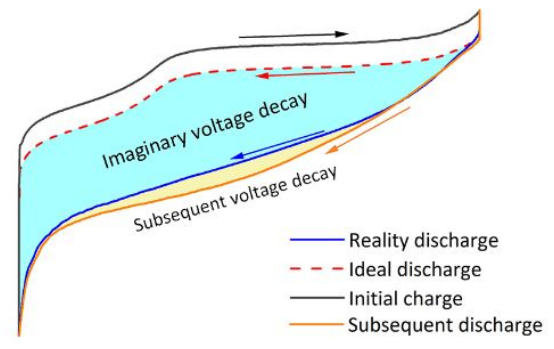

Figure S7. a. schematic diagram of structure evolution during the initial cycle. b. Charge/discharge profiles of a typical LLOs. The dash line represents an ideal discharge curve by assumed reversible phase transition. 
a

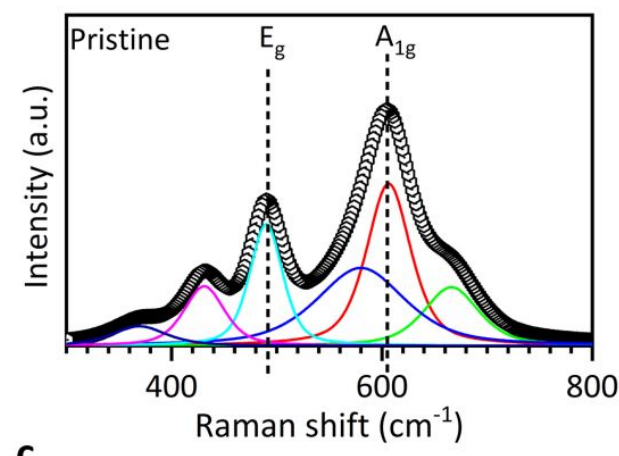

C

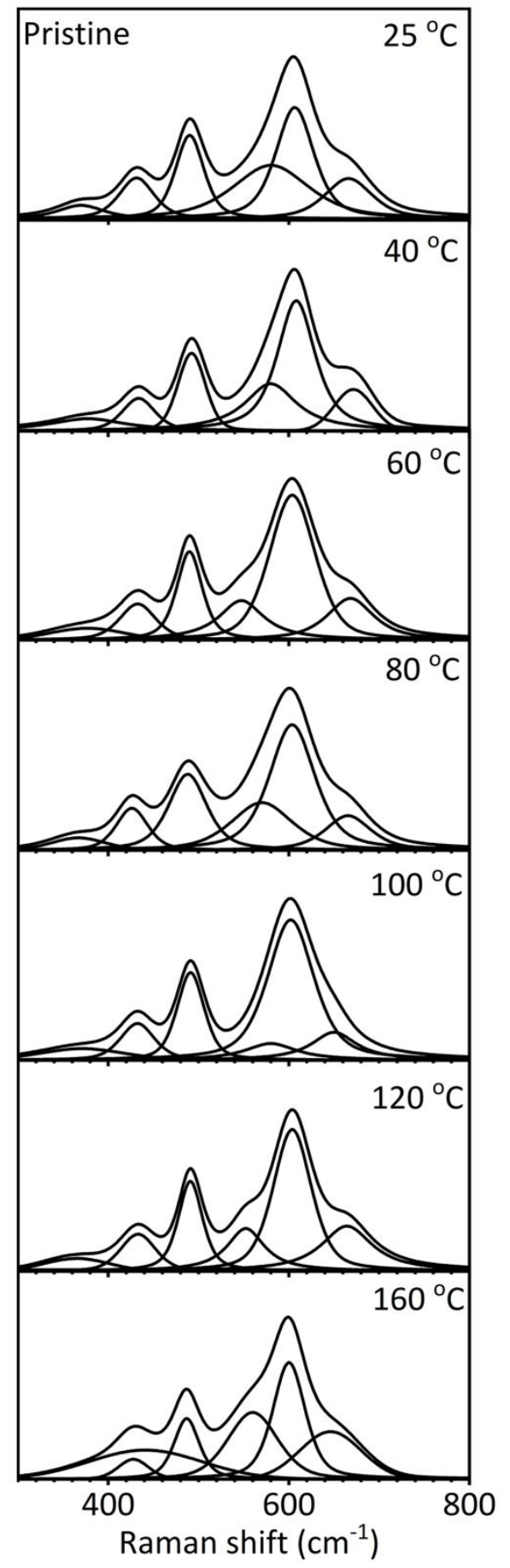

b
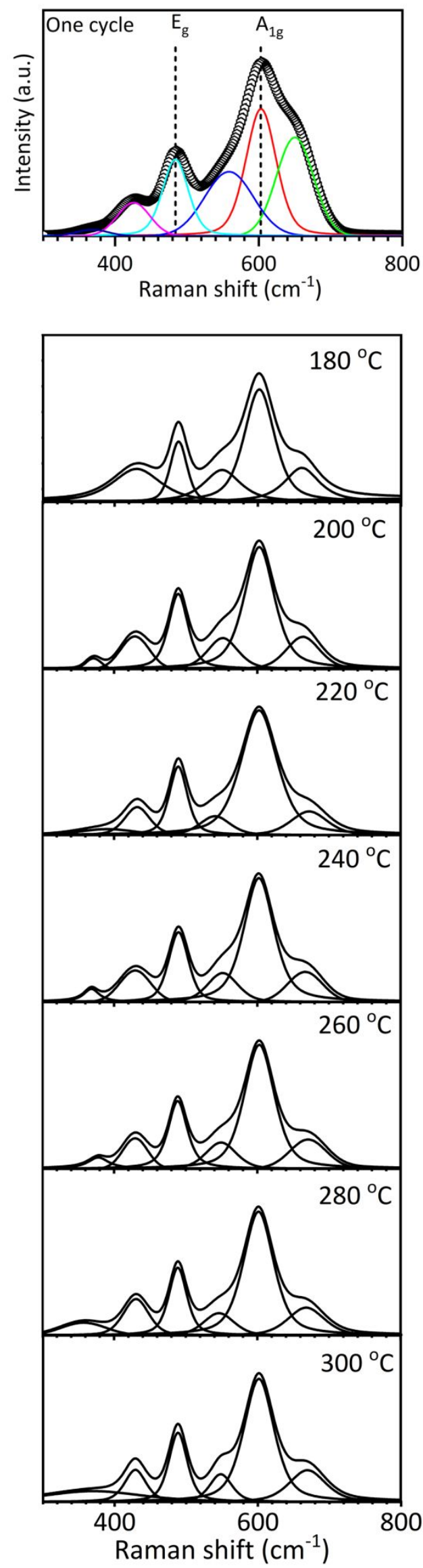
d
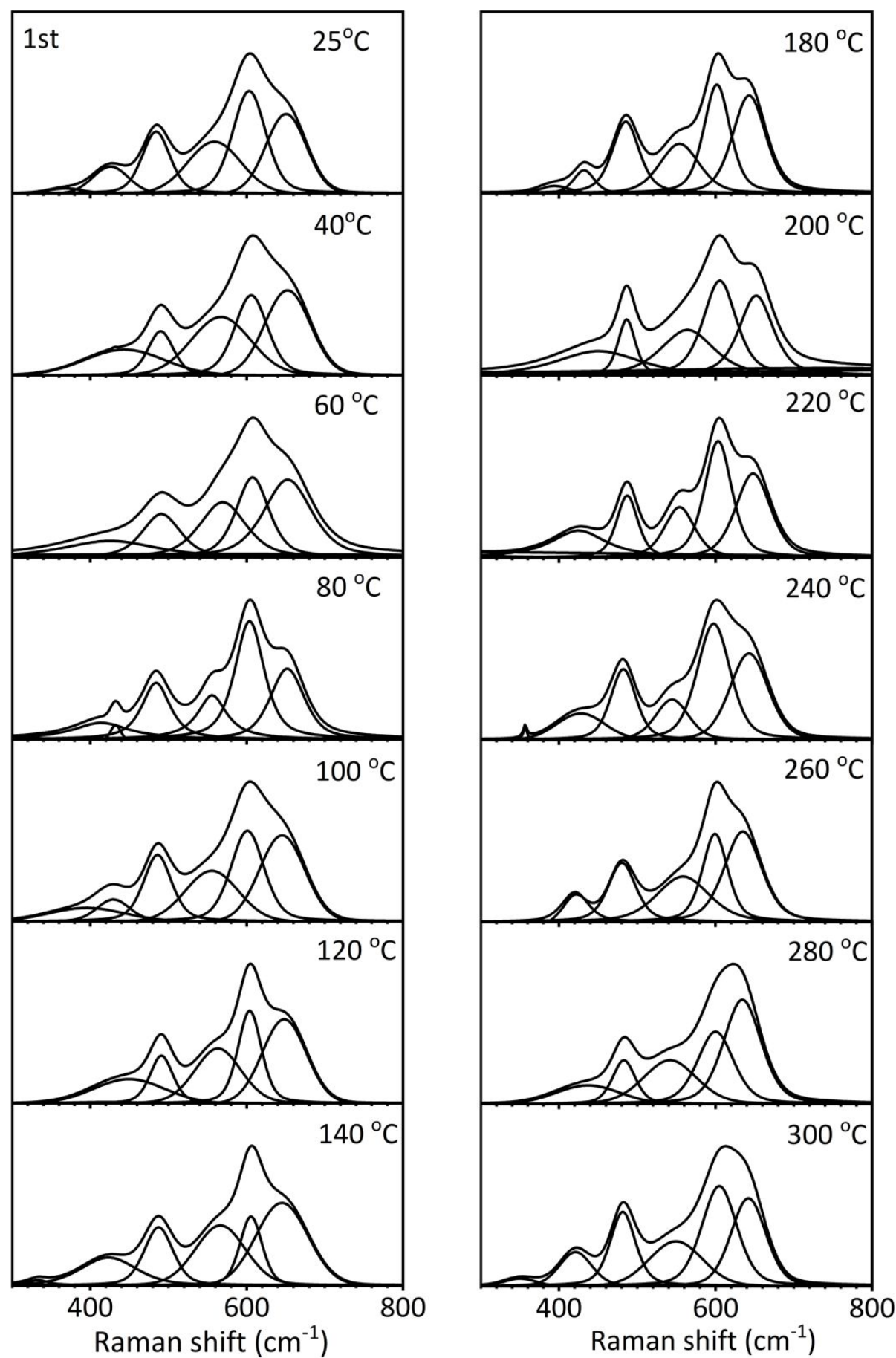

Figure S8. Peak fittings of the in(ex) situ Raman spectrum for the pristine and one-cycled $\mathrm{Li}_{1.26} \mathrm{Ni}_{0.0741} \mathrm{Co}_{0.0741} \mathrm{Mn}_{0.593} \mathrm{O}_{2}$ 
Table S1. A comparison of voltage decay rate using different modification strategies.

\begin{tabular}{|c|c|c|c|c|c|}
\hline Formula & Method & $\begin{array}{l}\text { Cut-off } \\
\text { voltage }\end{array}$ & $\begin{array}{l}\text { Maximal } \\
\text { Capacity }\end{array}$ & $\begin{array}{l}\text { Optimal voltage } \\
\text { decay rate }\end{array}$ & $\begin{array}{l}\text { Referenc } \\
\text { e }\end{array}$ \\
\hline $\mathrm{Li}_{1.2} \mathrm{Ni}_{0.13} \mathrm{Co}_{0.13} \mathrm{Mn}_{0.54}$ & Mixing with $\mathrm{MgSO}_{4}$ & $2.0 \sim 4.8 \mathrm{~V}$ & 250 & $1.15 \mathrm{mV}$ per cycle & 6 \\
\hline $\mathrm{O}_{2}$ & & & $\mathrm{mAh} \mathrm{g}^{-1}$ & at $1 \mathrm{C}$ & \\
\hline $\mathrm{Li}_{1.2-\mathrm{x}} \mathrm{Na}_{\mathrm{x}}\left[\mathrm{Ni}_{0.13} \mathrm{Co}_{0.13}\right.$ & Na substitution & $2.0 \sim 4.8 \mathrm{~V}$ & 246.8 & $1.60 \mathrm{mV}$ per cycle & 7 \\
\hline $\left.\mathrm{Mn}_{0.54}\right] \mathrm{O}_{2}$ & & & mAh $g^{-1}$ & at $300 \mathrm{~mA} \mathrm{~g}^{-1}$ & \\
\hline \multirow[t]{2}{*}{$\mathrm{Li}_{1.2} \mathrm{Ni}_{0.2} \mathrm{Mn}_{0.6} \mathrm{O}_{2}$} & $\mathrm{CoF}_{2}$ coating & $2.0 \sim 4.8 \mathrm{~V}$ & 264.4 & $3.12 \mathrm{mV}$ per cycle & 8 \\
\hline & & & mAh g-1 & at $0.1 \mathrm{C}$ & \\
\hline \multirow{2}{*}{$\mathrm{Li}_{1.2} \mathrm{Mn}_{0.56} \mathrm{Ni}_{0.16} \mathrm{Co}_{0.08} \mathrm{O}_{2}$} & Morphology & $2.0 \sim 4.8 \mathrm{~V}$ & $\sim 270$ & $0.84 \mathrm{mV}$ per cycle & 9 \\
\hline & modification & & $\mathrm{mA} \mathrm{h} \mathrm{g} \mathrm{g}^{-1}$ & at $0.5 \mathrm{C}$ & \\
\hline \multirow[t]{2}{*}{$\mathrm{Li}_{1.11} \mathrm{Ni}_{0.33} \mathrm{Mn}_{0.56} \mathrm{O}_{2}$} & Al doping \& $\mathrm{Al}_{2} \mathrm{O}_{3}$ & $2.5 \sim 4.6 \mathrm{~V}$ & $\sim 230$ & $1.8 \mathrm{mV}$ per cycle at & 10 \\
\hline & coating & & $m A h g^{-1}$ & $0.2 \mathrm{C}$ & \\
\hline \multirow[t]{2}{*}{$\mathrm{Li}_{1.20} \mathrm{Ni}_{0.13} \mathrm{Co}_{0.13} \mathrm{Mn}_{0.54} \mathrm{O}_{2}$} & Gradient particle & $2.0 \sim 4.8 \mathrm{~V}$ & $\sim 275$ & $1.5 \mathrm{mV}$ per cycle at & 11 \\
\hline & & & $m A h g^{-1}$ & $0.5 \mathrm{C}$ & \\
\hline $\mathrm{Li}_{1.22} \mathrm{Mn}_{0.55} \mathrm{Ni}_{0.115} \mathrm{Co}_{0.115}$ & Spinel coating & $2.0 \sim 4.8 \mathrm{~V}$ & 300 & $1.9 \mathrm{mV}$ per cycle at & 12 \\
\hline $\mathrm{O}_{2}$ & & & $\mathrm{mAh} \mathrm{g}^{-1}$ & $0.5 \mathrm{C}$ & \\
\hline $\mathrm{Li}_{1.2} \mathrm{Ni}_{0.13} \mathrm{Co}_{0.13} \mathrm{Mn}_{0.51} \mathrm{Ru}_{0}$ & Ru doping & $2.0 \sim 4.8 \mathrm{~V}$ & 268 & $1.6 \mathrm{mV}$ per cycle at & 13 \\
\hline $.03 \mathrm{O}_{2}$ & & & $\mathrm{mAh} \mathrm{g}^{-1}$ & $1 \mathrm{C}$ & \\
\hline This work & Constructing & $2.0 \sim 4.8 \mathrm{~V}$ & 280 & $1.25 \mathrm{mV}$ per cycle & \\
\hline & disorder structure & & $m A h g^{-1}$ & at $0.5 \mathrm{C}$ & \\
\hline
\end{tabular}


Table S2. Detailed structural parameters for the joint Retiveld refinement using the single phase model.

\begin{tabular}{lcccll}
\hline $\mathrm{Li}_{1.259} \mathrm{Ni}_{0.0741} \mathrm{Co}_{0.0741} \mathrm{Mn}_{0.593} \mathrm{O}_{2}$. Space group: $\mathrm{R}-3 \mathrm{~m}$ & \\
$\mathrm{a}=\mathrm{b}=2.82661(13), \mathrm{c}=14.13164(126)$ & & \\
atom & site & $\mathrm{x}$ & $\mathrm{y}$ & $\mathrm{z}$ & $\mathrm{Occ}$ \\
\hline $\mathrm{Li}$ & $3 \mathrm{a}$ & 0 & 0 & 0 & $0.996(0)$ \\
$\mathrm{Ni}$ & & 0 & 0 & 0 & $0.004(0)$ \\
$\mathrm{Co}$ & $3 b$ & 0 & 0 & 0.5 & 0.072 \\
$\mathrm{Mn}$ & & 0 & 0 & 0.5 & 0.588 \\
$\mathrm{Ni}$ & & 0 & 0 & 0.5 & $0.072(0)$ \\
$\mathrm{Li}$ & & 0 & 0 & 0.5 & $0.264(0)$ \\
$\mathrm{O}$ & $6 \mathrm{c}$ & 0 & 0 & $0.24296(25)$ & 1 \\
\hline
\end{tabular}


Table S3. Detailed structural parameters for the joint Retiveld refinement using the two-phase model.

\begin{tabular}{|c|c|c|c|c|c|}
\hline \multicolumn{6}{|c|}{$\begin{array}{l}\text { Phase } 1 \text { composition: } \mathrm{LiNi}_{1 / 3} \mathrm{Co}_{1 / 3} \mathrm{Mn}_{1 / 3} \mathrm{O}_{2} \text {. Space group: } \mathrm{R}-3 \mathrm{~m} \text {. } \\
\text { Phase fraction: } 28.18(11.40) \% . \quad \mathrm{a}=\mathrm{b}=2.82498(18), \mathrm{c}=14.12540(177)\end{array}$} \\
\hline atom & site & $x$ & y & $z$ & Occ. \\
\hline $\mathrm{Li}$ & $3 a$ & 0 & 0 & 0 & $0.96(0)$ \\
\hline $\mathrm{Ni}$ & & 0 & 0 & 0 & $0.04(0)$ \\
\hline Co & $3 b$ & 0 & 0 & 0.5 & 0.334 \\
\hline $\mathrm{Mn}$ & & 0 & 0 & 0.5 & 0.333 \\
\hline $\mathrm{Ni}$ & & 0 & 0 & 0.5 & 0.293 \\
\hline $\mathrm{Li}$ & & 0 & 0 & 0.5 & 0.04 \\
\hline 0 & $6 c$ & 0 & 0 & $0.24388(47)$ & 1 \\
\hline \multicolumn{6}{|c|}{$\begin{array}{l}\text { Phase } 2 \text { composition: } \mathrm{Li}_{2} \mathrm{MnO}_{3} \text {. Space group: } \mathrm{C} 2 / \mathrm{m} \text {. Phase fraction: } 71.82(8.86) \% \\
\mathrm{a}=4.90672(138), b=8.49175(268), c=4.98640(113), \beta=109.03033^{\circ}(2242)\end{array}$} \\
\hline atom & site & $x$ & $y$ & $z$ & Occ. \\
\hline $\mathrm{Li}$ & $2 b$ & 0 & 0.5 & 0 & 1 \\
\hline $\mathrm{Li}$ & $2 c$ & 0 & 0 & 0.5 & 1 \\
\hline $\mathrm{Li}$ & $4 \mathrm{~h}$ & 0 & $0.70622(741)$ & 0.5 & 1 \\
\hline $\mathrm{Mn}$ & $4 g$ & 0 & $0.17158(140)$ & 0 & 1 \\
\hline 0 & $4 i$ & $0.24029(837)$ & 0 & $0.22369(700)$ & 1 \\
\hline 0 & $8 j$ & $0.25112(574)$ & $0.33057(325)$ & $0.22727(384)$ & 1 \\
\hline
\end{tabular}




\section{References}

1. Assat, G.; Foix, D.; Delacourt, C.; ladecola, A.; Dedryvere, R.; Tarascon, J. M., Fundamental Interplay between Anionic/Cationic Redox Governing the Kinetics and Thermodynamics of Lithium-Rich Cathodes. Nature Communications 2017, 8, 2219.

2. Hammersley, A. P., ESRF Internal Report, EXP/AH/95-01, FIT2D V5.18 Reference Manual V1.6. 1995.

3. Zhang, J.; Xia, Y.; Wang, Y.; Xie, C.; Sun, G.; Liu, L.; Pang, B.; Li, J.; Huang, C.; Liu, Y.; Gong, J., High Resolution Neutron Diffractometer HRND at Research Reactor CMRR. Journal of Instrumentation 2018, 13, T01009-T01009.

4. Carvajal, J. R., Introduction to the Program FullPROF: Refinement of Crystal and Magnetic Structures from Powder and Single Crystal Data.

5. Rietveld, H. M., Line Profiles of Neutron Powder-Diffraction Peaks for Structure Refinement. 1967, 22, 151-152.

6. Xue, J.; Wang, Y.; Sun, C.; Xu, P.; Fan, X.; Fan, J.; Zheng, M.; Dong, Q., Suppressing voltage fading and improving cycling stability of Li-rich $\mathrm{Mn}$-based materials by introducing $\mathrm{MgSO}_{4}$. Journal of Materials Chemistry A 2020, 8, 22763-22772.

7. Chen, S.; Chen, Z.; Xia, M.; Cao, C.; Luo, Y., Toward Alleviating Voltage Decay by Sodium Substitution in Lithium-Rich Manganese-Based Oxide Cathodes. ACS Applied Energy Materials 2018, 1, 4065-4074.

8. Chong, S.; Chen, Y.; Yan, W.; Guo, S.; Tan, Q.; Wu, Y.; Jiang, T.; Liu, Y., Suppressing capacity fading and voltage decay of Li-rich layered cathode material by a surface nano-protective layer of $\mathrm{CoF}_{2}$ for lithium-ion batteries. Journal of Power Sources 2016, 332, 230-239.

9. He, X.; Wang, J.; Wang, R.; Qiu, B.; Frielinghaus, H.; Niehoff, P.; Liu, H.; Stan, M. C.; Paillard, E.; Winter, M.; Li, J., A 3D porous Li-rich cathode material with an in situ modified surface for high performance lithium ion batteries with reduced voltage decay. Journal of Materials Chemistry $A$ 2016, 4, 7230-7237.

10. Phattharasupakun, N.; Geng, C.; Johnson, M. B.; Väli, R.; Liu, A.; Liu, Y.; Sawangphruk, M.; Dahn, J. R., Impact of Al Doping and Surface Coating on the Electrochemical Performances of LiRich Mn-Rich $\mathrm{Li}_{1.11} \mathrm{Ni}_{0.33} \mathrm{Mn}_{0.56} \mathrm{O}_{2}$ Positive Electrode Material. Journal of The Electrochemical Society 2020, 167.

11. Ju, X.; Hou, X.; Beuse, T.; Liu, Z.; Du, L.; Brinkmann, J. P.; Paillard, E.; Wang, T.; Winter, M.; Li, J., Tailoring of Gradient Particles of Li-Rich Layered Cathodes with Mitigated Voltage Decay for Lithium-Ion Batteries. ACS Appl Mater Interfaces 2020, 12, 43596-43604.

12. Peng, H.; Zhao, S. X.; Huang, C.; Yu, L. Q.; Fang, Z. Q.; Wei, G. D., In Situ Construction of Spinel Coating on the Surface of a Lithium-Rich Manganese-Based Single Crystal for Inhibiting Voltage Fade. ACS Appl Mater Interfaces 2020, 12, 11579-11588.

13. Shang, H.; Ning, F.; Li, B.; Zuo, Y.; Lu, S.; Xia, D., Suppressing Voltage Decay of a Lithium-Rich Cathode Material by Surface Enrichment with Atomic Ruthenium. ACS App/ Mater Interfaces 2018, 10, 21349-21355. 